\title{
Campus Adaptations of Engineering Undergraduates by Gender
}

Ms. Vijayalakshmi N.S.

\author{
Research Scholar, School of Management, National Institute of Technology Karnataka, Surathkal, Mangalore
}

\author{
Dr. A.H. Sequeira
}

Professor, School of Management, National Institute of Technology Karnataka, Surathkal, Mangalore

\section{Doi:10.5901/mjss.2017.v8n3p305}

\begin{abstract}
The study aims to empirically test the relationship between types of campus adaptations across gender engineering undergraduate B.Tech students alone pursuing a four year study at Indian Institute of Technology (IIT's) and National Institute of Technology (NIT's) in India. The independent $t$ - test was run with SPSS vs 21 to determine the nature of campus adaptations of IIT's and NIT's between undergraduate male students $(n=1268)$ and female students of $(n=152)$ with the multistage random sample of $n=1420$. There is a significant relationship on campus adaptations among students by gender indicating that; campus adaptations did vary which could be attributed to the lower strength of the sample size. However, if a qualitative approach is adopted with interviews held to seek out information on nature of adaptability to campus environments, it could introspect more in-depth on the nature and levels of adaptability of female students witnessing challenges at campuses of higher learning.
\end{abstract}

Keywords: Campus, Adaptation, Academic, Social, Physical - Psychological, Institutional, engineering undergraduates

\section{Introduction}

Gender equality is a lame equality as knowledge continues to be male centric (Y. Liu \& Wang, 2009). The gender gap in current school enrolment selection among "irregular" student impacts participation of students in higher education ( $L$. Morley, Leach, \& Lugg, 2009). Gender stereotypes surround girl and technology (Johnson, 2009) where gender stereotype theory focuses on low level of enrolment in science among women (Delisle, Guay, Senécal, \& Larose, 2009). The gender differentials in education exploring the capabilities approach in India (Unni, 2009) views higher education equity as a say on income equity distribution (Gao, Zhao, \& Xing, 2009) with perspective on board of how women engineers do and undo gender (A. Powell, Bagilhole, \& Dainty, 2009) contributing to future mapping on international perspectives on gender in engineering education research (Beddoes, Borrego, \& Jesiek, 2009). This discloses that perceptions and role of women in engineering is changing among women (Kongar, Kontogiorgis, Russo, \& Sobh, 2009). The saviour in time for this could be sharing personal stories as informal learning experience on women's learning experience in science and engineering (Sahib \& Vassileva, 2009b). To this however the 'downside' of women empowerment in India an experimental inquiry into the role of expectations (Kempen, 2009) is often felt to extend student pipeline in engineering towards women students (P. Doerschuk et al., 2009) as when a person thinks of engineer, it's that "think engineer think male" reveres the gender image of engineer (Male, Bush, \& Murray, 2009). Further the transformative possibilities of feminisms in engineering education (Riley, Pawley, Tucker, \& Catalano, 2009) is finding more women and diversity in engineering fields (Hopewell, McNeely, Kuiler, \& Hahm, 2009) that could transform women in non-traditional sectors of the economy with less gender segregation in workplace (Potter \& Hill, 2009). It's a teaser to worry about women in science (Rosser \& Taylor, 2009) though the larger concern would be women stand out as a highly efficient way of shaping more gender-equitable situation in higher education (Tjomsland, 2009)

Understanding women's underrepresentation in engineering (Morganson, Jones, \& Major, 2010) states back to identifying low representation of women in engineering with fewer opportunities than male peers and acutely feel the lack of role models, in work domain and indirect roles (A. E. Smith \& Dengiz, 2010). Education, hence by far is gender shaped (Apple, 2010) with feminism in engineering being just more than a girls talk (Larkin \& Quinn, 2010). Feminism on campus today (Agness, 2010) with feminist stand point theory on experiences of women college students (Cox \& Ebbers, 2010) vindictively pointing out that experience, motivation and gender difference in undergraduate studies persist (Mirjana, 2011). The door theory states that there are gender differences in attainment of engineering education (Ma, 2011) 
believing that human capita in India with transition probabilities of moving from a number of different educational levels to higher educational levels is low and worse for women in India (Chakrabarty \& Bhaumik, 2012) giving its confirmation that the legitimacy of female participation in engineering (Watermeyer, 2012) especially of women undergraduates in engineering education in India is growing (N. Gupta, 2012). Lastly the dilemmas of girls and women in engineering from masculine world versus feminine world(Saavedra, Araújo, Taveira, \& Vieira, 2013) with true stance for value of the capability policy model of world bank approach (Manion \& Menashy, 2013) need to look into student satisfaction that differs by gender (Strayhorn \& Johnson, 2014).

The study seeks to analyse the relationship among gender on campus adaptations of students with the following research question and research objective:

\subsection{Research Question}

What makes campus adaptations of academic, social, physical - psychological and institutional environments be unique by gender?

\subsection{Research Objectives}

To examine by gender among campus adaptations of academic, social, physical psychological and institutional environments.

\section{Campus Adaptation}

\subsection{Academic Adaptation}

It is vital to debunk myths on gender and academic achievement (Kane \& Mertz, 2012) as academic failure differs by gender where for male students teacher student interaction and socio demographic factors contribute towards it (Jeludar, Jeludar, Shayan, \& AhmadiGatab, 2012). The need for horizontal analysis of gender equality in different academic areas (Silander, Haake, \& Lindberg, 2013) stresses on academic experiences that differed among undergraduates on man hood and masculinity identities (Strayhorn \& Tillman-Kelly, 2013). Gender bias in engineering admission persists in Karnataka state of India (Rajasenan, 2014) as fundamentally its gender difference in learning styles that impact academic performance of students (Rahimabadi, 2014). Teachers' effect on students' creative self-beliefs is moderated by students' gender (Karwowski, Gralewski, \& Szumski, 2015). So gender difference exist in attitude, knowledge and career choice among students (Mudavanhu, 2016) influencing academic success (Altermatt \& Painter, 2016)

\subsection{Social Adaptation}

The transition of women students from higher education to industry is a poisoned chalice with short term benefits only (A. Powell, Dainty, \& Bagilhole, 2011) as socialisation process of engineering students differ by gender (Riney \& Froeschie, 2012). Attachment styles scores too differ in terms of gender and presence or absence of a romantic relationship in the past and their settlement (Tagay \& Karatas, 2012). In brief social experiences differed among undergraduates on man hood and masculinity identities (Strayhorn \& Tillman-Kelly, 2013) revering benevolent sexism with men's advantage on the prescription of warmth to women (Delacollette, Dumont, Sarlet, \& Dardenne, 2013) . In short females in science are affected by underlying gendered assumptions and structural power relationships (R. Watts, 2014).

\subsection{Physical-Psychological Adaptation}

\subsubsection{Physical adaptation}

Physical activity is found to be lower among female college students (Rajappan, Selvaganapathy, \& Liew, 2015) influencing psycho social adjustment and weight status (Y. Chang \& Halgunseth, 2015). The mindful eating among women college students can impact their physical health positively (Smart, Chisum, Robertson-pfeffer, \& Tsong, 2015) with reproductive health education towards safe sexual health behaviours among female students (Akinsoji, Olufunmilola, Idowu, \& Pius, 2015) could avoid the feeling of being unsafe on campus . Institutions safety provision should meet criteria's especially for sexual minority students (Mooij, 2015). Further gender difference in sleep deprivation impacts 
physical health (Ferrara et al., 2015) where cognitive performance of students is associated with sleep symptoms and sleep duration varying by gender (Sufrinko, Johnson, \& Henry, 2016). Moreover personality and alcohol expectancies discriminate alcohol consumption patterns among female students (Pilatti, Cupani, \& Pautassi, 2015). However motivation towards physical activity among women college students can positively impact health of college students (AlEisa et al., 2016)

\subsubsection{Psychological Adaptation}

Gender differences exist in applying social cognitive career theory in engineering students (Inda, Rodríguez, \& Peña, 2013). Emotional intelligence is related to gender, academic performance and intellectual capacity of university students (Sierra, del Rosal, Romero, Villegas, \& Lorenzo, 2013). Perception of masculinity persist among undergraduate male students (Fazli Khalaf, Low, Ghorbani, \& Merghati Khoei, 2013) that gender roles on technology self-efficacy impacts use of technology in higher education (Huffman, Whetten, \& Huffman, 2013). Self-efficacy the core construct in social cognitive career theory impacts persistence in engineering by gender (Saifuddin, Dyke, \& Rasouli, 2013) where persistence of women in engineering careers is also due to self-efficacy on the challenges and novelty associated with the profession (Buse, Bilimoria, \& Perelli, 2013). Gender and emotional intelligence impacts emotional self-efficacy among undergraduates (Tariq, Qualter, Roberts, Appleby, \& Barnes, 2013) making demographic determinants of gender, age and life environment on academic adaptation towards stress among first year students (Clinciu, 2013). Lastly though stress and its coping strategies differ among college students by gender (D. S. Lee \& Padilla, 2014); self-esteem and gender was negatively correlated with anxiety among college students (Mustafa, Melonashi, Shkembi, Besimi, \& Fanaj, 2015).

\subsection{Institutional Adaptation}

Female graduates from elite institutions have lower labour market involvement(Hersch, 2013) as the discourse of academic major choice determines persistence of gender inequalities in higher education in engineering (Beddoes \& Pawley, 2013). It is the supportive environment that persists women in non traditional fields like science and engineering (Galeshi, 2013)barging against the tide of stereotypes on undergraduate womens achievement and identification towards persistence(B. D. Jones, Ruff, \& Paretti, 2013). Gender Role Attitudes of Female Students in Single-Sex insitution is better off than in coeducational institution(Erarslan \& Rankin, 2013). This is evident in the Gender Gaps in College Attendance and Completion(Flashman, 2013). Much more evidently, locality of the institute impacts academic achievement of students (Raju, Chitttoor, \& Pradesh, 2013). Off recent, academic website impression and its navigation by gender(Ramakrishnan, Prybutok, \& Peak, 2014) has its aura on choice of institution by gender(Squire \& Mobley, 2014) playing its major stroke of impact on college experiences and there on towards degree completion among four year institutions (Gayles \& Ampaw, 2014). Lastly, Off-campus house too serve as signs of cultural texts on gender and sexuality(Weinzimmer \& Twill, 2015) with gender, distance from home,and duration of stay at dormitory significantly impacting students attachment to place or institution(M. Xu, de Bakker, Strijker, \& Wu, 2015)

The study proposes the following research hypothesis:

$\mathrm{H}_{0}$ :- Campus adaptations of academic, social, physical - psychological and institutional adaptations did not differ by gender among undergraduate students .

$\mathrm{H}_{1}$ :- Campus adaptation of academic, social, Physical - Psychological and institutional adaptations varied by gender among undergraduate students.

\section{Methods}

\subsection{Participant}

The reference population were undergraduate 4-year B. tech students enrolled on a regular study mode at IIT's and NIT's. A total of 1460 students participated with 1420 of valid responses for an overall 97.26 percent participation rate after deducting the questionnaire that contained empty answers. Data was collected for 20 weeks across institutions of IIT's and NIT's. Of the 1420 undergraduate respondents $89.29 \%$ were male students and $10.70 \%$ were female students. 


\subsection{Sampling}

Probability sampling technique with multistage sampling followed by cluster sampling in identification of institutes of IIT's and NIT's was adopted. This is followed up with stratified sampling in sample choice of undergraduate students' population and simple random in collecting data from the chosen student population stated above.

\subsection{Instrument and Procedure}

The survey was conducted using a structured online questionnaire with reference to student's campus and non - campus email accounts. At all times, the students were informed of the anonymous, confidential, and voluntary nature of their participation and any doubts that arose were clarified.

\subsection{Measures}

All the 21 items in the questionnaire were measured with rating on a five point Likert scale ranging from " 1 = strongly disagree" to " 5 = strongly Agree". Reliability and validity of the questionnaire was tested.

\section{Data Analysis}

\subsection{Independent t-test}

On an average, male students $(n=1268)$ had higher level of academic adaptation $(M=2.62, S E=0.0199)$ than female students $(n=152)$ with $(M=2.40, S E=0.049)$. This mean difference of $0.224, \mathrm{BCa} 95 \% \mathrm{Cl}[0.11945,0.32938]$, was significant at $t(203.584)=4.215, \quad p=0.000(p \leq 0.05)$.

On an average, female students $(n=152)$ had higher level of social adaptation $(M=2.79, S E=0.05)$ than male students $(n=1268)$ with $(M=2.71, S E=0.021)$. The mean difference of $-0.077, \mathrm{BCa} 95 \% \mathrm{Cl}[-0.19675,0.04114]$ was not significant at $t(197.111)=-1.290, p=0.199(p>0.05)$.

On average female students $(n=152)$ had higher level of physical - psychological adaptation with $(M=2.30, S E$ $=0.050)$ than of male students $(M=2.28, \mathrm{SE}=0.022)$. The mean difference of $-0.0150, \mathrm{BCa} 95 \%, \mathrm{Cl}[-0.12361,0.09354]$ was not significant at $t(213.782)=-0.273, p=0.785(p>0.05)$

On average male students $(n=1268)$ had higher level of institutional adaptation with $(M=2.15, S E=0.022)$ than of female students $(n=152)$ with $(M=2.09, S E=0.05)$. This mean difference of () .059$), B C a 95 \%$ Cl $[-0.07241,-0.19187]$ was not significant at $t(1418)=0.887, p=0.375(p>0.05)$

In short, we accept the alternate hypothesis $\left(\mathrm{H}_{1}\right)$ that there is a substantial difference in campus adaptations of academic, social, physical - psychological, institutional adaptations among students by gender.

\section{Conclusion}

Undoing gender at campus though has remained a debated concept for long. The work towards equality in higher education is pacing up slowly much to the distraught of educationalists where tracking the gap leaves things questionable. The diligence of support to success is though on active pedagogy and pushing towards cutting edge of content, the nourishment stimulation and engagement of students is always transcending through their mind body and soul. The creative and compassionate education to know themselves inside out with power and potential; is the way to navigate the inner self of the girl which is filled with confidence and aspirations. So it's time for every one of us to leave the concept of gender to be baked a little more always and chance upon not 'equal opportunity' but pounce of 'every opportunity' as for a girl to embrace on an educational path of fulfilment is not for one side of the coin in terms of gender alone but it's more for a humane cause that could help glass ceiling come crashing down all way for future generations to come.

\section{Implications}

It is vital to prepare a class of women to the notion of reality i.e. efficiently transcend the path from mere participation to transformation so that a system of higher education is created helping out more and more students to trust their inner voices more to which they sincerely lean out. The spaces in those superficial statistics need to share bigger picture of 
radical ideas with enhanced and pronounced voices of female students. This cross sectional study paves way for ample scope of future work on similar lines with longitudinal study that could significantly highlight the persistent need for introspection of adaptability of female students at multi institutional campuses

\section{References}

A, A., L, D., \& Manickam, L. (2014). shyness and Masculinitiy - feminity of Adolescents living in thier homes and those staying at hostels in mysore. Indian Journal of Psychology, 51, 5-12.

Adeyemi, K., \& Akpotu, N. (2004a). Gender analysis of student enrolment in Nigerian universities. Higher Education, 48(3), 361-378. http://doi.org/10.1023/B:HIGH.0000035547.19318.27

Agness, K. L. (2010). For Members Only: Feminism on Campus Today. Academic Questions, 23(2), $177-185$. http://doi.org/10.1007/s12129-010-9158-y

Akinsoji, A. A., Olufunmilola, A.-A. O., Idowu, A. A., \& Pius, A.-O. I. (2015). Sexual and Contraceptive Practices among Female Undergraduates in a Nigerian Tertiary Institution. Ethiopian Journal of Health Sciences, 25(3), $209-16$. http://doi.org/10.4314/ejhs.v25i3.3

Al-Eisa, E., Al-Rushud, A., Alghadir, A., Anwer, S., Al-Harbi, B., Al-Sughaier, N., ... Al-Muhaysin, H. A. (2016). Effect of motivation by "instagram" on adherence to physical activity among female college students. BioMed Research International, 2016(FEBRUARY). http://doi.org/10.1155/2016/1546013

Al-Khatib, B. A., Awamleh, H. S., \& Samawi, F. S. (2012). Student's Adjustment to College Life at Albalqa Applied University. American International Journal of Contemporary Research, 2(11), 7-16. Retrieved from http://www.aijcrnet.com/journals/Vol_2_No_11_November_2012/2.pdf

Altermatt, E. R., \& Painter, J. K. (2016). I Did Well. Should I Tell? Gender Differences in Children's Academic Success Disclosures. Sex Roles, 74(1-2), 46-61. http://doi.org/10.1007/s11199-015-0549-y

Apple, R. D. (2010). How gender shaped science and education: A history of nutritional sciences in the 19th and 20th centuries. Frontiers of Education in China, 5(2), 177-185. http://doi.org/10.1007/s11516-010-0012-3

Baytiyeh, H., Baytiyeh, B. H., \& Engineer, C. (2012). AC 2012-3533: WOMEN ENGINEERS IN THE MIDDLE EAST FROM ENROLLMENT TO CAREER : A CASE STUDY Women Engineers in the Middle East from Enrollment to Career : A Case Study. In American Society for Engineering Education, 2012 (pp. 1-9).

Beddoes, K., Borrego, M., \& Jesiek, B. K. (2009). Mapping international perspectives on gender in engineering education research. In Proceedings - Frontiers in Education Conference, FIE (pp. 1-6). http://doi.org/10.1109/FIE.2009.5350766

Beddoes, K., \& Pawley, A. L. (2013). "Different people have different priorities": work-family balance, gender, and the discourse of choice. Studies in Higher Education, 39(9), 1573-1585. http://doi.org/10.1080/03075079.2013.801432

Brainard, S., \& Carlin, L. (1997b). A longitudinal study of undergraduate women in engineering and science. Teaching and Learning in an Era of Change Proceedings, 1, 134-143. Retrieved from http://ieeexplore.ieee.org/xpls/abs_all.jsp?arnumber=644826

Buse, K., Bilimoria, D., \& Perelli, S. (2013). Why they stay: women persisting in US engineering careers. Career Development International, 18(2), 139-154. http://doi.org/http://dx.doi.org/10.1108/CDI-11-2012-0108

Chakrabarty, M., \& Bhaumik, S. K. (2012). Whither human capital? The woeful tale of transition to tertiary education in India. Applied Economics Letters, 19(9), 835-838. http://doi.org/10.1080/13504851.2011.607109

Chang, Y., \& Halgunseth, L. C. (2015). Early Adolescent's Psychosocial Adjustment and Weight Status Change: The Moderating Roles of Gender, Ethnicity, and Acculturation. Journal of Youth and Adolescence, 44(4), 870-886. http://doi.org/10.1007/s10964-014$0162-3$

Clinciu, A. I. (2013). Adaptation and Stress for the First Year University Students. Procedia - Social and Behavioral Sciences, 78, 718722. http://doi.org/10.1016/j.sbspro.2013.04.382

Cox, E. M., \& Ebbers, L. H. (2010). Exploring the Persistence of Adult Women at a Midwest Community College. Community College Journal of Research and Practice, 34(4), 337-359. http://doi.org/10.1080/10668920802545088

Delacollette, N., Dumont, M., Sarlet, M., \& Dardenne, B. (2013). Benevolent Sexism, Men's Advantages and the Prescription of Warmth to Women. Sex Roles, 68(5-6), 296-310. http://doi.org/10.1007/s11199-012-0232-5

Delisle, M. N., Guay, F., Senécal, C., \& Larose, S. (2009). Predicting stereotype endorsement and academic motivation in women in science programs: A longitudinal model. Learning and Individual Differences, 19(4), $468-475$. http://doi.org/10.1016/j.lindif.2009.04.002

Doerschuk, P., Bahrim, C., Daniel, J., Kruger, J., Mann, J., \& Martin, C. (2009). Work in progress - STAIRSTEP - A program for expanding the student pipeline. In Proceedings - Frontiers in Education Conference, FIE (pp. 1-2). http://doi.org/10.1109/FIE.2009.5350566

DORON, R. (1992). "To Be Or Not To Be An Educator?":The Dilemma Facing the Engineering Teacher. European Journal of Engineering Education, 17(4), 421-426. http://doi.org/10.1080/03043799208923197

$\mathrm{Du}, \mathrm{X} . \mathrm{Y}$. (2006). Gendered practices of constructing an engineering identity in a problem-based learning environment. European Journal of Engineering Education, 31(1), 35-42. http://doi.org/10.1080/03043790500430185

Erarslan, A. B., \& Rankin, B. (2013). Gender Role Attitudes of Female Students in Single-Sex and Coeducational High Schools in Istanbul. Sex Roles, 69(7-8), 455-468. http://doi.org/10.1007/s11199-013-0277-0

Fazli Khalaf, Z., Low, W. Y., Ghorbani, B., \& Merghati Khoei, E. (2013). Perception of masculinity amongst young Malaysian men: a 
qualitative study of university students. BMC Public Health, 13(1), 1062. http://doi.org/10.1186/1471-2458-13-1062

Fernandez, R., Fogli, A., \& Olivetti, C. (2002a). Marrying Your Mom: Preference Transmission and Women's Labour and Education Choices. Discussion Paper Series- Centre for Economic Policy Research London, (3592), ALL. http://doi.org/10.3386/w9234

Ferrara, M., Bottasso, A., Tempesta, D., Carrieri, M., De Gennaro, L., \& Ponti, G. (2015). Gender differences in sleep deprivation effects on risk and inequality aversion: Evidence from an economic experiment. PLOS ONE, 10(3). http://doi.org/10.1371/journal.pone.0120029

Fettahlioğlu, P. (2011). The analysis of using self-regulated learning strategies according to gender factor. Procedia - Social and Behavioral Sciences, 15, 2748-2752. http://doi.org/10.1016/j.sbspro.2011.04.182

Flashman, J. (2013). A Cohort Perspective on Gender Gaps in College Attendance and Completion. Research in Higher Education, 54(5), 545-570. http://doi.org/10.1007/s11162-013-9285-8

Fulton, J. J., Marcus, D. K., \& Zeigler-Hill, V. (2014). Psychopathic Personality Traits, Risky Sexual Behavior, and Psychological Adjustment Among College-Age Women. Journal of Social and Clinical Psychology, 33(2), 143-168. http://doi.org/10.1521/jscp.2014.33.2.143

Galeshi, R. (2013). Women and Nontraditional Fields : A Comprehensive Review. Journal of Sustainability Education, 4(January), 1-13.

Gao, S., Zhao, S., \& Xing, H. (2009). A study on the relationship between higher education equity and income distribution based on cointegration and granger causality test. In Proceedings - 2009 International Conference on Computational Intelligence and Software Engineering, CiSE 2009 (pp. 9-12). http://doi.org/10.1109/CISE.2009.5364759

Gardner, S. K. (2013). Women Faculty Departures from a Striving Institution: Between a Rock and a Hard Place. The Review of Higher Education, 36(3), 349-370. http://doi.org/10.1353/rhe.2013.0025

Gayles, J. G., \& Ampaw, F. (2014). The Impact of College Experiences on Degree Completion in STEM Fields at Four-Year Institutions: Does Gender Matter? The Journal of Higher Education, 85(4), 439-468. http://doi.org/10.1353/hhe.2014.0022

Ginther, donna k, \& Hayes, kathy j. (2003). gender differences in salary and promotion for faculty in the humanities 1977 - 95 . The Journal of Human Resources, 38(1), 34-73.

Gupta, N. (2012). Women Undergraduates in Engineering Education in India: A Study of Growing Participation. Gender, Technology and Development, 16(2), 153-176. http://doi.org/10.1177/097185241201600202

Hersch, J. (2013). Opting out among women with elite education. Review of Economics of the Household, 11(4), 469-506. http://doi.org/10.1007/s11150-013-9199-4

Holland, L., Matthews, T. L., \& Schott, M. R. (2013). "That's So Gay!" Exploring College Students' Attitudes Toward the LGBT Population. Journal of Homosexuality, 60(October), 575-595. http://doi.org/10.1080/00918369.2013.760321

Hopewell, L. a., McNeely, C. L., Kuiler, E. W., \& Hahm, J. O. (2009). University leaders and the public agenda: Talking about women and diversity in STEM fields. Review of Policy Research, 26(5), 589-607. http://doi.org/10.1111/j.1541-1338.2009.00407.x

Hornsby, E. E., Morrow-Jones, H. a., \& Ballam, D. a. (2012). Leadership Development for Faculty Women at The Ohio State University: The President and Provost's Leadership Institute. Advances in Developing Human Resources, 14(1), 96-112. http://doi.org/10.1177/1523422311428758

Huffman, A. H., Whetten, J., \& Huffman, W. H. (2013). Using technology in higher education: The influence of gender roles on technology self-efficacy. Computers in Human Behavior, 29(4), 1779-1786. http://doi.org/10.1016/j.chb.2013.02.012

Inda, M., Rodríguez, C., \& Peña, J. V. (2013). Gender differences in applying social cognitive career theory in engineering students. Journal of Vocational Behavior, 83(3), 346-355. http://doi.org/10.1016/j.jvb.2013.06.010

Jeludar, S. S., Jeludar, Z. A., Shayan, N., \& AhmadiGatab, T. (2012). Factors Affecting the Academic Failure of Male Students. Procedia - Social and Behavioral Sciences, 46, 2575-2578. http://doi.org/10.1016/.sbspro.2012.05.526

Johnson, N. F. (2009). Contesting Binaries: Teenage Girls as Technological Experts. Gender, Technology and Development, 13(3), 365-383. http://doi.org/10.1177/097185241001300303

Jones, B. D., Ruff, C., \& Paretti, M. C. (2013). The impact of engineering identification and stereotypes on undergraduate women's achievement and persistence in engineering. Social Psychology of Education, 16(3), 471-493. http://doi.org/10.1007/s11218013-9222-x

Kane, J. M., \& Mertz, J. E. (2012). Debunking Myths about Gender and Mathematics Performance. Notices of the American Mathematical Society, 59(1), 10-21. http://doi.org/10.1090/noti790

Karwowski, M., Gralewski, J., \& Szumski, G. (2015). Teachers' Effect on Students' Creative Self-Beliefs Is Moderated by Students' Gender. Learning and Individual Differences, 44(February 2016), 1-8. http://doi.org/10.1016/j.lindif.2015.10.001

Kempen, L. van. (2009). The "Downside" of Women Empowerment in India: An Experimental Inquiry into the Role of Expectations. Social Indicators Research, 94(3), 465-482. http://doi.org/10.1007/sl

Kongar, E., Kontogiorgis, P., Russo, N. L., \& Sobh, T. M. (2009). Women in Science, Engineering and Technology: Changing roles and Perceptions within the Technical Services Industries. Journal of Engineering and Applied Sciences, 4(1), 46-50.

Krause, S., Burrows, V., Sutor, J., \& Carlson, M. (2007). Addressing gender equity pipeline issues with a workshop for high school mathematics and science teachers. In Proceedings - Frontiers in Education Conference, FIE (pp. 9-14). http://doi.org/10.1109/FIE.2007.4417955

KVANDE, E. (1986). Factors Affecting Women's Decision to Study at the Technical University of Norway NTH). European Journal of Engineering Education, 11(3), 295-302. http://doi.org/10.1080/03043798608939310

Larkin, T. L., \& Quinn, C. M. (2010). The feminine side of engineering: It's way more than just "Girl talk!" In Proceedings - Frontiers in Education Conference, FIE (pp. 1-5). http://doi.org/10.1109/FIE.2010.5673124 
Lee, D. S., \& Padilla, A. M. (2014). Acculturative Stress and Coping: Gender Differences Among Korean and Korean American University Students. Journal of College Student Development, 55(3), 243-262. http://doi.org/10.1353/csd.2014.0025

Litzler, E., Samuelson, C. C., \& Lorah, J. a. (2014). Breaking it Down: Engineering Student STEM Confidence at the Intersection of Race/Ethnicity and Gender. Research in Higher Education, 55(8), 810-832. http://doi.org/10.1007/s11162-014-9333-z

Liu, L. (2012). FEMALE FRIENDLY DSP CURRICULUM FOR EXPANDING WOMEN ' S OPPORTUNITIES. IEEE, $2757-2760$.

Liu, Y., \& Wang, Z. (2009). Women entering the elite group: A limited progress. Frontiers of Education in China, 4(1), 27-55. http://doi.org/10.1007/s11516-009-0003-4

Lord, S. M., Brawner, C. E., Camacho, M. M., Layton, R. A., Long, R. A., Ohland, M. W., \& Wasburn, M. H. (2008). Work in progresseffect of climate and pedagogy on persistence of women in engineering programs. In 38th ASEE/IEEE Frontiers in Education Conference (pp. 21-22). Retrieved from http://ieeexplore.ieee.org/xpls/abs_all.jsp?arnumber=4720502

Lord, S. M., Camacho, M. M., Layton, R. a., Long, R. a., Ohland, M. W., \& Wasburn, M. H. (2009). Who'S Persisting in Engineering? a Comparative Analysis of Female and Male Asian, Black, Hispanic, Native American, and White Students. Journal of Women and Minorities in Science and Engineering, 15(2), 167-190. http://doi.org/10.1615/JWomenMinorScienEng.v15.i2.40

Ma, Y. (2011). Gender Differences in the Paths Leading to a STEM Baccalaureate. Social Science Quarterly, 92(5), 1169-1190. http://doi.org/10.1111/j.1540-6237.2011.00813.x

Maithani, A., Misra, M., Potnis, S., \& Bhuwania, S. (2012). The Effect of Gender on Perception of Glass Ceiling, Mediated by SRO and Attitude toward Women as Managers. Management and Labour Studies, 37(2), $107-123$. http://doi.org/10.1177/0258042X1203700203

Malbergier, A., Cardoso, L. R. D., Abrantes do Amaral, R., \& Santos, V. C. V. (2012). Gender parity and drug use: are girls catching up with boys? Revista Brasileira de Psiquiatria, 34(1), 16-23. http://doi.org/10.1590/S1516-44462012000100005

Male, S. a, Bush, M. B., \& Murray, K. (2009). Think engineer, think male? European Journal of Engineering Education, 34(5), 455-464. http://doi.org/10.1080/03043790903137759

Manion, C., \& Menashy, F. (2013). The Prospects and Challenges of Reforming the World Bank's Approach to Gender and Education: Exploring the Value of the Capability Policy Model in The Gambia. Journal of Human Development and Capabilities, 14(2), 1-27. http://doi.org/10.1080/19452829.2012.693909

Marra, R., Bogue, B., Rodgers, K. A., \& Shen, D. (2007). Self-efficacy of women engineering students: three years of data at U.S. institutions. American Society for Engineering Education.

Marschke, R., Laursen, S., Nielsen, J. M., \& Dunn-Rankin, P. (2007). Demographic Inertia Revisited: An Immodest Proposal to Achieve Equitable Gender Representation among Faculty in Higher Education. The Journal of Higher Education, 78(1), 1-26. http://doi.org/10.1353/jhe.2007.0003

Mirjana, I. (2011). The IT Gender Gap Experience, Motivation and Differences in Undergraduate Studies of Computer Science.pdf. Turkish Online Journal of Distance Education-TOJDE, 12(2), 170-186.

Mooij, T. (2015). School Indicators of Violence Experienced and Feeling Unsafe of Dutch LGB Versus Non-LGB Secondary Students and Staff, 2006-2010. Journal of Interpersonal Violence, (June), 886260515585527. http://doi.org/10.1177/0886260515585527

Morganson, V. J., Jones, M. P., \& Major, D. a. (2010). Understanding Women 's Underrepresentation in Science , Technoiogy , Engineering, and iVlathematics: The Role of Sociai Coping. Development, 59(December), 169-180.

Morley, L., Leach, F., \& Lugg, R. (2009). Democratising higher education in Ghana and Tanzania: Opportunity structures and social inequalities. International Journal of Educational Development, 29(1), 56-64. http://doi.org/10.1016/j.ijedudev.2008.05.001

Mudavanhu, Y. (2016). A study of the Year 10 students ' gender differences in attitudes, knowledge of chemistry and career choice. http://doi.org/10.13140/RG.2.1.1994.3443

Mustafa, S., Melonashi, E., Shkembi, F., Besimi, K., \& Fanaj, N. (2015). Anxiety and Self-esteem among University Students: Comparison between Albania and Kosovo. Procedia - Social and Behavioral Sciences, 205(May), $189-194$. http://doi.org/10.1016/j.sbspro.2015.09.057

Pilatti, A., Cupani, M., \& Pautassi, R. M. (2015). Personality and alcohol expectancies discriminate alcohol consumption patterns in female college students. Alcohol and Alcoholism, 50(4), 385-392. http://doi.org/10.1093/alcalc/agv025

Potter, M., \& Hill, M. (2009). Women into non-traditional sectors: addressing gender segregation in the Northern Ireland workplace. Journal of Vocational Education \& Training, 61(2), 133-150. http://doi.org/10.1080/13636820902933239

Powell, A., Bagilhole, B., \& Dainty, A. (2009). How women engineers do and undo gender: Consequences for gender equality. Gender, Work and Organization, 16(4), 411-428. http://doi.org/10.1111/j.1468-0432.2008.00406.x

Powell, A., Dainty, A., \& Bagilhole, B. (2011). A poisoned chalice? Why UK women engineering and technology students may receive more "help" than their male peers. Gender and Education, 23(5), 585-599. http://doi.org/10.1080/09540253.2010.527826

Rahimabadi, R. K. (2014). Assessment of male and female university students ' learning styles and academic performance. Journal of Middle East Applied Science and Technology, (SEPTEMBER), 1-2.

Rahman, Z., \& Witenstein, M. A. (2013). A quantitative study of cultural conflict and gender differences in South Asian American college students. Ethnic and Racial Studies, 37(6), 1121-1137. http://doi.org/10.1080/01419870.2012.753152

Rajappan, R., Selvaganapathy, K., \& Liew, L. (2015). Physical Activity Level Among University Students: a Cross Sectional Survey. International Journal of Physiotherapy and Research, 3(6), 1336-1343. http://doi.org/10.16965/ijpr.2015.202

Rajasenan, D. (2014). Gender Bias and Caste Exclusion in Engineering Admission: Inferences from the Engineering Entrance Examination in Kerala. Higher Education for the Future, 1(1), 11-28. http://doi.org/10.1177/2347631113518275

Raju, S. S., Chitttoor, D., \& Pradesh, A. (2013). Impact Of Gender And Locality on Academic Achievement of Secondary School 
Students in Social Studies. Indian Journal of Research, (february), 106-107.

Raley, R. K., Kim, Y., \& Daniels, K. (2012). Young Adults' Fertility Expectations and Events: Associations With College Enrollment and Persistence. Journal of Marriage and Family, 74(4), 866-879. http://doi.org/10.1111/j.1741-3737.2012.00990.x

Ramakrishnan, T., Prybutok, V., \& Peak, D. A. (2014). The moderating effect of gender on academic website impression. Computers in Human Behavior, 35, 315-319. http://doi.org/10.1016/j.chb.2014.02.018

Reed, B., \& Case, J. (2003). Factors influencing learners ' choice of Mechanical Engineering as a career. African Journal of Research in Mathematics, Science and Technology Education, 7, 73-83.

Riley, D., Pawley, A. L., Tucker, J., \& Catalano, G. D. (2009). Feminisms in engineering education: Transformative possibilities. NWSA Journal, 21(2), 21-40. http://doi.org/10.1353/nwsa.0.0076

Riney, M., \& Froeschie, J. (2012). Socialization Processes of Engineering Students: Differences in the Experiences of Females and Males. Administrative Issues Journal, 2(1), 96-106. http://doi.org/10.5929/2011.2.1.9

Rosser, S. V, \& Taylor, M. Z. (2009). Why Are We Still Worried about Women in Science? Academe, 95(3), 6-10.

Saavedra, L., Araújo, A. M., Taveira, M. D. C., \& Vieira, C. C. (2013). Dilemmas of girls and women in engineering: a study in Portugal. Educational Review, 66(3), 330-344. http://doi.org/10.1080/00131911.2013.780006

Saavedra, L., Araújo, A. M., Taveira, M. do C., \& Vieira, C. C. (2014). Dilemmas of girls and women in engineering: a study in Portugal. Educational Review, 66(3), 330-344. http://doi.org/10.1080/00131911.2013.780006

Saewyc, E. M., Brown, D., Plane, M., Mundt, M. P., Zakletskaia, L., Wiegel, J., \& Fleming, M. F. (2009). Gender Differences in Violence Exposure Among University Students Attending Campus Health Clinics in the United States and Canada. Journal of Adolescent Health, 45(6), 587-594. http://doi.org/10.1016/j.jadohealth.2009.03.024

Saffarpoor, S., Farahbakhsh, K., Shafiabadi, A., \& Pashasharifi, H. (2013). A comparison between the effectiveness of solution-focused brief therapy and the quadripartite model of social competence and a fusion model of these two methods on increasing social adjustment of female students residing in Tehran dormitories. Journal of Applied Social Psychology, 43(3), 562-569. http://doi.org/10.1111/j.1559-1816.2013.01036.x

Sagas, M., \& Cunningham, G. B. (2004). Does having "the right stuff" matter? Gender differences in the determinants of career success among intercollegiate athletic administrators. Sex Roles, 50(March), 411-421. http://doi.org/Doi 10.1023/B:Sers.0000018895.68011.Fa

Sahib, Z., \& Vassileva, J. (2009a). Designing to attract participation in a niche community for women in science \& engineering. In Proceedings - 12th IEEE International Conference on Computational Science and Engineering, CSE 2009 (Vol. 4, pp. 909-914). http://doi.org/10.1109/CSE.2009.442

Saifuddin, S. M., Dyke, L. S., \& Rasouli, M. (2013). Gender and careers: a study of persistence in engineering education in Bangladesh. Gender in Management, 28(4), 188-209. http://doi.org/http://dx.doi.org/10.1108/GM-01-2013-0009

Sekaquaptewa, D. (2011). Discounting Their Own Success: A Case for the Role of Implicit Stereotypic Attribution Bias in Women's STEM Outcomes. Psychological Inquiry, 22(June 2013), 291-295. http://doi.org/10.1080/1047840X.2011.624979

Selimbegovic, L., Chatard, A., \& Mugny, G. (2007). Can we encourage girls' mobility towards science-related careers? Disconfirming stereotype belief through expert influence. European Journal of Psychology of Education, 22(3), 275-290. http://doi.org/10.1007/BF03173426

Shilling, C. (1991). Educating the Body: Physical Capital and the Production of Social Inequalities. Sociology, 25(4), 653-672. http://doi.org/10.1177/0038038591025004006

Sierra, M. de los D. V., del Rosal, M. Á. B., Romero, N. R., Villegas, K., \& Lorenzo, M. (2013). La inteligencia emocional y su relación con el género, el rendimiento académico y la capacidad intelectual del. alumnado universitario. Electronic Journal of Research in Educational Psychology, 11(2), 395-412. http://doi.org/10.14204/ejrep.30.12204

Silander, C., Haake, U., \& Lindberg, L. (2013). The different worlds of academia: a horizontal analysis of gender equality in Swedish higher education. Higher Education, 66(2), 173-188. http://doi.org/10.1007/s10734-012-9597-1

Smart, R., Chisum, A., Robertson-pfeffer, K., \& Tsong, Y. (2015). Women 's Experience with a Mindful Eating Course on a University Campus : A Pilot Study. Californian Journal of Health Promotion, 13(1), 59-65.

Smith, A. E., \& Dengiz, B. (2010). Women in engineering in Turkey-a large scale quantitative and qualitative examination. European Journal of Engineering Education, 35(1), 45-57. Retrieved from http://www.tandfonline.com/doi/abs/10.1080/03043790903406345

Smith, T. (1991). Survival in the Academic Arena: Advice for Women Faculty. In 1991 Frontiers In Education Conference (pp. 278-281).

Squire, D. D., \& Mobley, S. D. (2014). Negotiating Race and Sexual Orientation in the College Choice Process of Black Gay Males. The Urban Review. http://doi.org/10.1007/s11256-014-0316-3

Strayhorn, T. L., \& Johnson, R. M. (2014). Black Female Community College Students' Satisfaction: A National Regression Analysis. Community College Journal of Research and Practice, 38(6), 534-550. http://doi.org/10.1080/10668926.2013.866060

Strayhorn, T. L., \& Tillman-Kelly, D. L. (2013). Queering Masculinity: Manhood and Black Gay Men in College. Spectrum: A Journal on Black Men, 1(2), 83-110. http://doi.org/10.2979/spectrum.1.2.83

Sufrinko, A., Johnson, E. W., \& Henry, L. C. (2016). The influence of sleep duration and sleep-related symptoms on baseline neurocognitive performance among male and female high school athletes. Neuropsychology, 30(4), 484-491. http://doi.org/10.1037/neu0000250

Tagay, O., \& Karatas, Z. (2012). An Investigation of Attachment Styles of College Students. Procedia - Social and Behavioral Sciences, 47, 745-750. http://doi.org/10.1016/j.sbspro.2012.06.728 
Tariq, V. N., Qualter, P., Roberts, S., Appleby, Y., \& Barnes, L. (2013). Mathematical Literacy in Undergraduates: Role of Gender, Emotional Intelligence and Emotional Self-Efficacy. International Journal of Mathematical Education in Science and Technology, 44(8), 1143. http://doi.org/10.1080/0020739X.2013.770087

Terry, B. S., Briggs, B. N., \& Rivale, S. (2011). Work in progress: Gender impacts of relevant robotics curricula on high school students' engineering attitudes and interest. In Proceedings - Frontiers in Education Conference, FIE (pp. 4-6). http://doi.org/10.1109/FIE.2011.6143090

Tjomsland, M. (2009). Women in Higher Education: A Concern for Development? . Gender, Technology and Development , 13(3), 407427. http://doi.org/10.1177/097185241001300305

Unni, J. (2009). Gender Differentials in Education: Exploring the Capabilities Approach. Economic and Political Weekly, xliv(9), $111-117$.

Van Anders, S. M. (2004). Why the academic pipeline leaks: Fewer men than women perceive barriers to becoming professors. Sex Roles, 51(9-10), 511-521. http://doi.org/10.1007/s11199-004-5461-9

Waller, A. a., Riley, D., Cashman, E., Eschenbach, E., \& Lord, S. (2006). Workshop classroom border crossings: Incorporating feminist and liberative pedagogies in your CSET classroom. In Proceedings - Frontiers in Education Conference, FIE (pp. 4-7). http://doi.org/10.1109/FIE.2006.322580

Watermeyer, R. (2012). Confirming the legitimacy of female participation in science, technology, engineering and mathematics (STEM): evaluation of a UK STEM initiative for girls. British Journal of Sociology of Education, 33(March 2015), 679-700. http://doi.org/10.1080/01425692.2012.678751

Watts, R. (2014). Females in science: a contradictory concept? Educational Research, 56(2), 126-136. http://doi.org/10.1080/00131881.2014.898910

Weber, K. (2012). Gender Differences in Interest, Perceived Personal Capacity, and Participation in STEM-Related Activities. Journal of Technology Education, 24(1), 18-33. Retrieved from http://scholar.lib.vt.edu/ejournals/JTE/v24n1/weber.html

Weinzimmer, J., \& Twill, S. (2015). Understanding "The Panty Shanty": off-campus house signs as cultural texts on gender and sexuality. Journal of Gender Studies, 9236(September), 1-15. http://doi.org/10.1080/09589236.2014.1000284

Weisgram, E. S., Dinella, L. M., \& Fulcher, M. (2011). The Role of Masculinity/Femininity, Values, and Occupational Value Affordances in Shaping Young Men's and Women's Occupational Choices. Sex Roles, 65(3), 243-258. http://doi.org/10.1007/s11199-0119998-0

Werner, L. L., Hanks, B., \& McDowell, C. (2004). Pair-programming helps female computer science students. Journal on Educational Resources in Computing, 4(1), 4-es. http://doi.org/10.1145/1060071.1060075

Xu, M., de Bakker, M., Strijker, D., \& Wu, H. (2015). Effects of distance from home to campus on undergraduate place attachment and university experience in China. Journal of Environmental Psychology, 43, 95-104. http://doi.org/10.1016/j.jenvp.2015.05.013

You, S. (2013). Gender and ethnic differences in precollege mathematics coursework related to science, technology, engineering, and mathematics (STEM) pathways. School Effectiveness and School Improvement, 24(1), 64-86. http://doi.org/10.1080/09243453.2012.681384

Zapata, M., Gallard, A. J., \& Gallard, a. J. (2007). Female science teacher beliefs and attitudes: Implications in relation to gender and pedagogical practice. Cultural Studies of Science Education, 2(4), 923-959. http://doi.org/10.1007/s11422-007-9069-6

Zhou, T., \& Zhou, Z. (2006). An empirical study of communication between teachers and students in colleges and universities. Frontiers of Education in China, 1(1), 79-88. http://doi.org/10.1007/s11516-005-0014-8

Zimmermann, L. (2011a). It 's a boy ! Women and non-monetary benefits from a son in India. Seminar.

Zinovyeva, N., \& Bagues, M. F. (2011). Does gender matter for academic promotion? Evidence from a randomized natural experiment.

Zotareli, V., Faúndes, A., Osis, M. J. D., Duarte, G. A., \& Sousa, M. H. de. (2012). Gender and sexual violence among students at a brazilian university. Revista Brasileira de Saúde Materno Infantil, (April), 37-46. http://doi.org/10.1590/S151938292012000100004 
ISSN 2039-2117 (online)

ISSN 2039-9340 (print)
Mediterranean Journal of Social Sciences MCSER Publishing, Rome-Italy
Vol 8 No 3

May 2017 